Dentin hassasiyet giderici ajanların dentin-adeziv siman bağlantısına etkisi: in-vitro çalışma

\title{
Effect of dentin desensitizing agents on dentin-adhesive cement bonding: an in-vitro study
}

\section{Prof. Dr. Övül Kümbüloğlu \\ Ege Üniversiteși, Diş Hekimliği Fakültesi, Protetik Diş Tedavisi A. D., İzmir}

\section{Dt. Nuray Sesli}

İpek Yolu Üzeri Yüksekova Devlet Hastanesi, Hakkari

\section{Dr. Makbule Heval Şahan}

Ege Üniversitesi, Diş Hekimliği Fakültesi, Protetik Diş Tedavisi A.D., İzmir

\section{Dr. Gözde Yerlioğlu}

Dentopolitan Diş Kliniği, İnkılap Mah. Küçüksu Cad. Ümraniye, İstanbul

Geliş Tarihi : 27 Mayıs 2016

Kabul tarihi: 23 Ağustos 2016

DOI: 10.5505/yeditepe.2016.46855

\section{Yazışma Adresi:}

Dr. Makbule Heval Şahan

Adres: Ege Üniversitesi Diş Hekimliği Fakültesi,

Protetik Diş Tedavisi A.D, Bornova, İzmir.

Tel: 02323112860

E-posta: heval.sahan@ege.edu.tr

\section{ÖZET}

Amaç: Periodontal tedavi, kırık, restoratif uygulamalar, çürük gibi nedenlerle koruyucu tabakanın kalkması sonucu dentin tübülleri açığa çıkıp dişte hassasiyet oluşunca hassasiyet giderici ajanlardan yararlanıır. Çalışmamızın amacı; postoperatif diş hassasiyetini gidermek için kullanılan hassasiyet giderici ajanların, adeziv simantasyondaki bağlantıya etkisini incelemektir.

Gereç ve Yöntem: 16 adet çürüksüz çekilmiş 3. büyük azı dişi rastgele iki gruba ayrıldı. Dişler PMMA bazlı soğuk akrilik içerisine yerleştirildi. Dişlerin okluzal yüzeyinde mine tabakası keskin frez ile kaldırılarak dentin tabakası açığa çıkartıldı. 1. gruptaki örneklere önce Gluma Desensitizer ve Gluma self etch bonding; sonra $4 \mathrm{~mm}$ çapında $3 \mathrm{~mm}$ yükseklikte silindir formunda SEcure adeziv siman uygulandı. 2. gruptaki örneklere ise önce Teethmate Desensitizer ve Clearfil universal bonding; sonra 4 mm çapında $3 \mathrm{~mm}$ yükseklikte silindir formunda SEcure adeziv siman uygulandı. Dentin örneklere termal siklus uygulandı. Hemen ardından örneklere üniversal test cihazında makaslama testi uygulandı. SEM incelenmesi ile desteklenerek elde edilen veriler istatiksel olarak değerlendirildi.

Bulgular: Teethmate Desensitizer hassasiyet giderici ajanın makaslama dayanımı değeri Gluma ajanına göre daha düşük bulundu. Her iki grup arasında istatistiksel fark anlamlıdır.

Sonuç: Gluma hassasiyet giderici ajan Teethmate Desensitizer'e göre daha yüksek bağlanma değeri gösterdi. Her iki grup içinde SEM analizinde koheziv kırıklar tespit edildi.

Anahtar Kelimeler: Dentin hassasiyeti, adezyon, dentin hassasiyet giderici ajanlar.

\section{SUMMARY}

Aim: The aim of the study is to research the effect that link is in adhesive cementation of dentin desensitizing agent, which use to desensitizate prosperative dental.

Materials and Methods: In this study, sixteen intact human third molar teeth were used. The teeth were randomly divided into two different groups (n: 8). Two different dentin desensitizer agents, Gluma and Teethmate Desensitizer, are used in the study. All samples were embedded into PMMA-based acrylic resin. The occlusal enamel tissues of teeth were removed to expose occlusal dentin. In the first group, firstly Gluma Desensitizer was applied to dentin surfaces according to manufacturer' instruction. Gluma self-etch was applied to dentin surfaces 
according to manufacturers' instructions. SEcure adhesive cement applied to dentin surface by means of cylindrical tubes. In the second group, firstly Teethmate Desensitizer was applied to dentin surfaces according to manufacturer' instruction. Clearfil universal bonding (Kuraray Medical Inc, Japan) was applied to dentin surfaces according to manufacturers' instructions. SEcure adhesive cement applied to dentin surface by means of cylindrical tubes. Shear bond strength test were performed by using Universal Tension/ Compression Testing Machine (Instron 3382, USA).

Results: The shear bond strength values of Teethmate Desensitizer groups were found statistically lower than the Gluma desensitizer groups $(p<0.05)$. There was statistically significant difference between the groups.

Conclusion: In this study, Gluma desensitizer shearbond strength values higher than Teethmate desensitizer. For both group, it is determined cohesive fractures in the SEM analysis.

Key words: Dentin hypersensitivity, adhesion, dentin desensitizer agent.

\section{GíRiş}

Dentin hassasiyeti, dentin yüzeyinde etkili olan uyaranlara cevap olarak oluşan ve uyaran ortadan kaldırıldıktan sonra geçen, herhangi patoloji sonucu oluşmayan kısa süreli keskin bir ağrıdır.' Diş hekimliğinde sıklıkla karşılaşılan dentin hassasiyeti; dentin dokusunun açığa çıkması ile olur. Hassasiyet süresi kısa olmasına rağmen; diş, dokunma uyarılarına karşı ani ve keskin yanıt verirken diğer uyaranlara ise künt yanıt verir. ${ }^{2}$

Çürük, dönen aletler, ısısal ve travmatik şok gibi farklı etkenler dentin ve pulpanın karşılaştığı uyaranlardır. Dentin hassasiyetinde, kavite preparasyonunda veya diş kesiminde kullanılan yüksek devirli kesici aletlerin oluşturduğu Isı, en sıklıkla karşılaşılan nedenidir. Oluşan ısı, dentin tübüllerinde Sıvı hareketine neden olur, dentin veya pulpadaki sinir uçları uyarılarak ağrı oluşur. ${ }^{3}$ Oluşan hassasiyeti azaltmak için açığa çıkmış dentin yüzeylerine bağlayıcı ajanların veya dentin hassasiyet gidericilerin uygulanması gerekmektedir. ${ }^{4}$

Açığa çıkmış dentin yüzeyine uygulanan hassasiyet giderici ajanlar tübüler tıkaç oluşturur. Böylelikle, hassasiyet giderici etkinin yanında tübül sıvı akışı da engellenir. Bu sebeple, dentin hassasiyet giderici ajanlar hibridizasyon 7tepeklinik açısından negatif etki sağlar. ${ }^{5}$ Klinik uygulamalar açısından, rezin-dentin bağlanma dayanımına dentin hassasiyet giderici ajanların etkisi önemlidir. Ancak, bu ajanların adeziv rezinlerin bağlanma dayanımına etkisiyle ilgili literatürde çelişkili sonuçlar vardır., 6,7,8,9

Çalışmamızın amacı; dentin hassasiyetinde kullanılan iki farklı preparatın adeziv simantasyondaki bağlantıya etkisinin karşılaştırılmalı olarak in vitro incelenmesidir.

\section{GEREÇ VE YÖNTEM}

Bu çalışma, Ege Üniversitesi Tıp Fakültesi Klinik Araştırmalar Etik Kurulu'nda onaylandı (Sayı: B.30.2.EGE.0.20.05.00/ OY/1567, Karar No: 15-10/1). Çalışmamızda 16 adet çürüksüz daimi 3. Büyük azı dişi kullanıldı. Çekimden hemen sonra dişler yumuşak doku artıklarından temizlenip akar su altında yıkandı. Dişler $+4^{\circ} \mathrm{C}$ distile suda 7 gün bekletildi. 7 günün sonunda dişler kole hizalarından pembe soğuk akrilikle milimetrik ölçü kalıplarının içine yerleştirildi. Dişlerin oklüzal yüzeylerindeki mine tabakası su soğutması altında orta grenli elmas fissür ve uca doğru incelen frez kullanılarak kaldırıldı. Bütün dişlerin okluzal yüzeyinde dentin tabakas açığa çıkartıldı (Resim 1). Dentin örneklerinin yüzeyi 320, 600, 800, 1000 grenli zımpara ile bol miktarda akan su ile zımparalandı. Musluk suyunda yıkandı ve hava spreyiyle hafif hava uygulanarak kurutuldu.

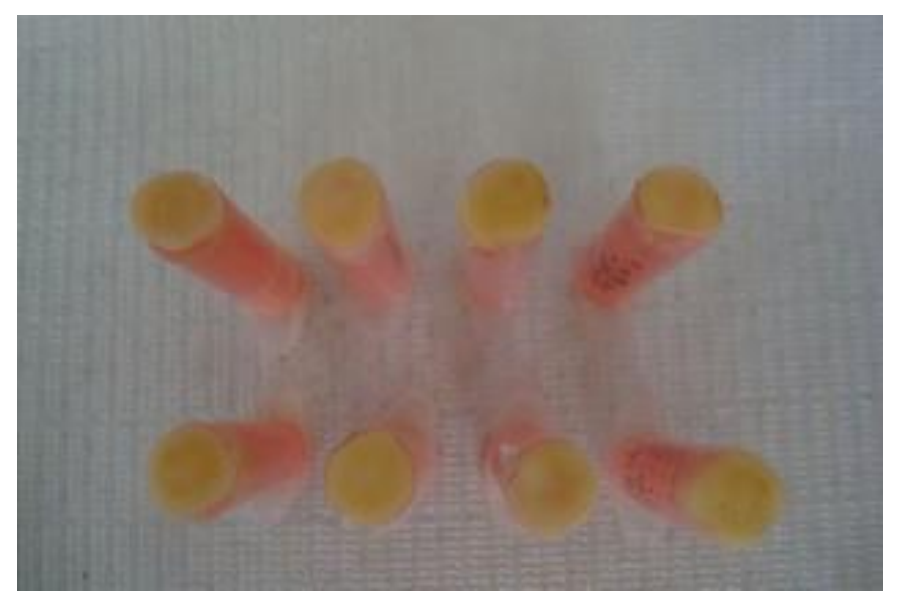

Resim 1: Örnekler üzerinde açığa çıkartılan dentin yüzeylerigörüntüsü

Oklüzal yüzeyleri uygun hale getirilen 16 adet dentin örneği, iki farklı hassasiyet giderici ajanın adeziv simantasyondaki bağlantıya etkisinin karşılaştırılmalı olarak incelenmesi amacıyla rastgele iki gruba ayrıldı: 1. grupta Gluma Desensitizer (Heraesus Kulzer, Almanya); 2. grupta Teethmate Desensitizer (Kuraray, Japonya) kullanıldı (Tablo 1). 


\begin{tabular}{|l|l|l|}
\hline $\begin{array}{l}\text { Hassasiyet Giderici } \\
\text { Ajan }\end{array}$ & Aktif Eleman & Üretici Firma \\
\hline Gluma Desensitizer & $\begin{array}{l}\% 5 \text { Gluteraldehit, } \\
\% 36 \text { HEMA }\end{array}$ & $\begin{array}{l}\text { Heraeus Kulzer, } \\
\text { Almanya }\end{array}$ \\
\hline $\begin{array}{l}\text { Teethmate Desensi- } \\
\text { tizer }\end{array}$ & Kalsiyum Fosfat & Kuraray, Japonya \\
\hline
\end{tabular}

Tablo 1. Çalışmada kullanılan hassasiyet giderici ajanlar ve içerikleri

1. gruptaki 8 adet dentin örneği, yağ içermeyen hava-su spreyi ile diş yüzeyleri yıkayıp kurutuldu ve Gluma Desensitizer (Heraeus Kulzer, Almanya) ince bir tabaka halinde tek kullanımlık fırça ile dişlerin oklüzal yüzlerine, üretici firmanın tavsiye ettiği şekilde uygulandı, 30-60 saniye beklendi

(Resim 2). Hassasiyet giderici ajanın üzerine, Gluma Self

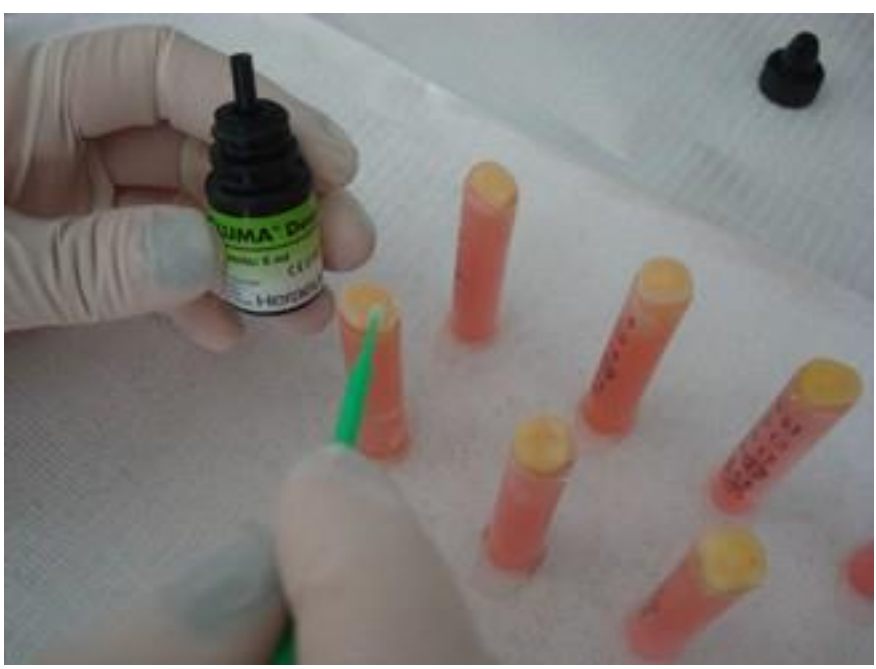

Resim 2: Birinci gruptaki örneklere Gluma desensitizer uygulanması

etch bond (Heraeus Kulzer, Almanya) ve SEcure (Sun Medical, Japonya) hem kimyasal hem ışıkla polimerize olan (dual cure) 4-META adeziv rezin içerikli siman üretici firmanın tavsiye ettiği şekilde uygulandı (Resim 3). Dentin örneklerinin yüzeyine eşit oranda malzeme uygulayabilmek için; $4 \mathrm{~mm}$ çapında, $3 \mathrm{~mm}$ yüksekliğinde şeffaf halkalar kullanıldı. Polimerizasyon için 40 saniye LED ışık kullanıldı. Her bir örnek için titizlikle bu uygulamalar gerçekleştirildi.

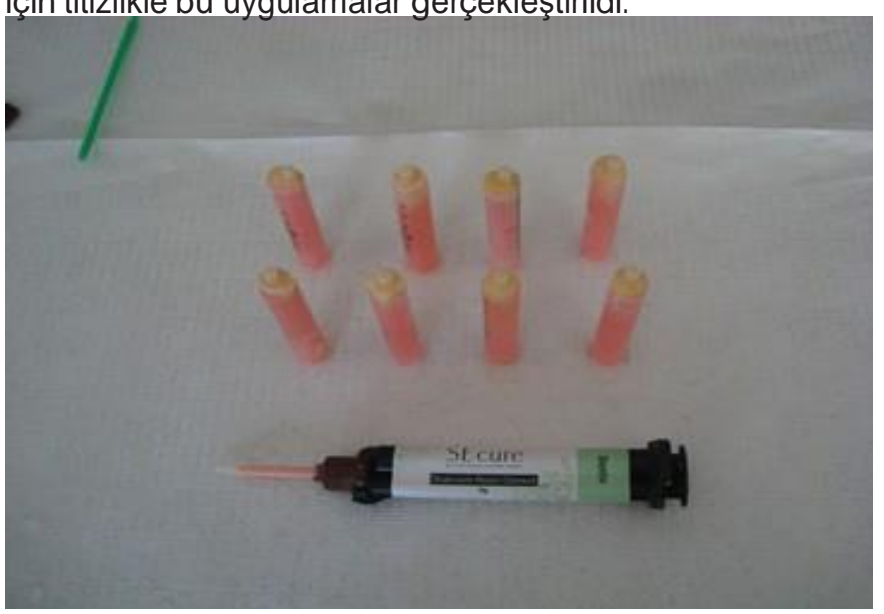

Resim 3: Birincigruptaki örneklere siman uygulanması
2. gruptaki 8 adet dentin örneğine Teethmate Desensitizer (Kuraray, Japonya) üretici firmanın tavsiye ettiği şekilde uygulandı. Yağ içermeyen hava-su spreyi ile diş yüzeyleri yıkayıp kurutuldu, ayrı tüplerde bulunan toz ve sıvısı tek kullanımlık özel kaplarında tek kullanımlık fırça ile 15 saniye karıştııldı, dişlerin okluzal yüzlerine 30 saniye boyunca uygulandı (Resim 4). Sonra dişlerin yüzeyi hava-su spreyi ile yıkanıp kurutuldu. Hassasiyet giderici ajanın üzerine, Clearfil universal bond (Kuraray, Japonya) ve siman olarak SEcure (Sun Medical, Japonya) 4-META adeziv rezin içerikli siman üretici firmanın tavsiye ettiği şekilde uygulandı (Resim 5). Polimerizasyon için 40 saniye LED ışık kullanıldı.

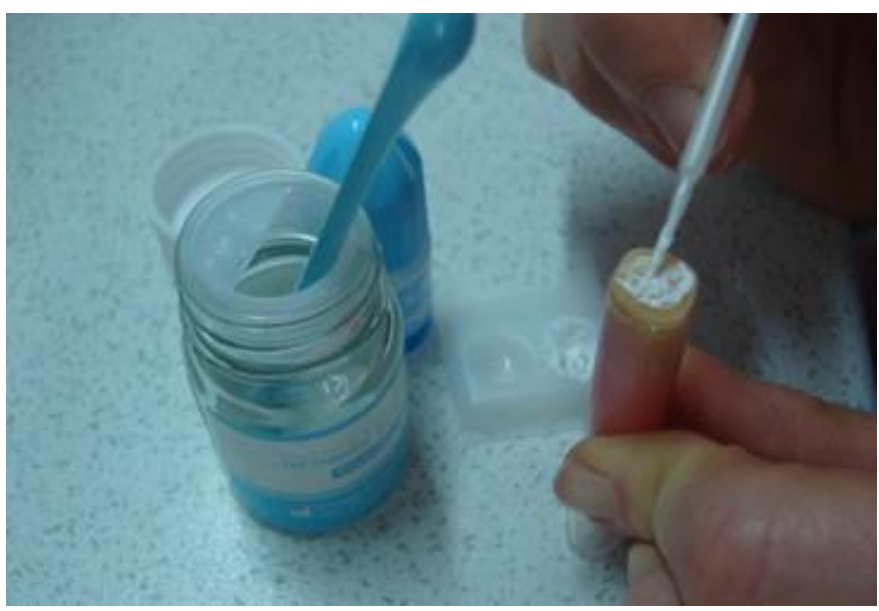

Resim 4: Ikinci gruptaki örneklere Teethmate Desensitizer uygulaması

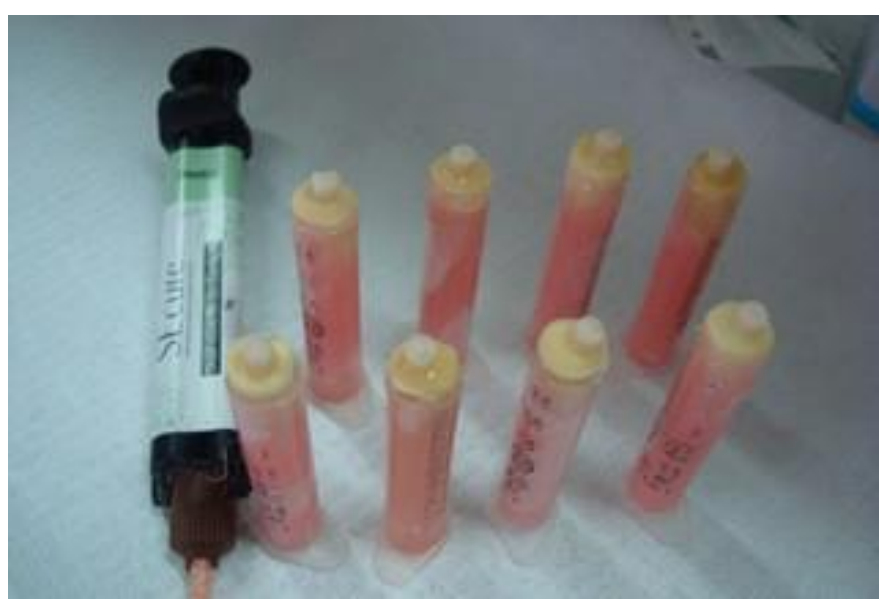

Resim 5: Íkinci gruptaki örneklere siman uygulanması

1. ve 2. gruptaki toplam 16 adet dentin örnek, bağlantı testinden önce ağız içi koşullarını taklit etmek amacıyla termal siklüs işlemine tabi tutuldu. Bu dentin örnekler, suda $5-55^{\circ} \mathrm{C}$ arasında 10 saniyelik aralıklar ile 1000 devirlik döngüyü Termal Siklus Cihazında tamamladı. Termal Siklüs işleminin sonucunda 2. gruba ait 2 adet örnekte, bağlantı testi öncesinde dentin yüzeyinden ayrılma görüldü.

Termal Siklus işleminden sonra hiç ara verilmeden 16 adet dentin örneğine Ege Üniversitesi Diş Hekimliği Fakültesi 
Araştırma Laboratuvarı'nda bulunan Üniversal Test Cihazında (AGS-J, SHIMADZU) 0,5 mm/dk hızında makaslama testi uygulandı. Elde edilen sonuçlar IBM SPSS 22,0 Programında One way ANOVA testinde istatiksel olarak değerlendirildi.

Makaslama testini takiben örneklere taramalı elektron mikroskobu (SEM) analizi, Ege Üniversitesi Diş Hekimliği Fakültesi SEM Laboratuvarı'nda yapıldı. Her örnek SEM ile incelendi. Örnekler karbon siman içeren alüminyum parçalara yerleştirildi. Değişik büyütmeler ile 14-16 mm mesafede $25 \mathrm{kV}$ ile yapıldı.Her deney örneğine ait makaslama testinin sonuçları kaydedildi.

Her iki gruptaki oklüzal yüzeydeki makaslama testi skorları parametrik olmayan istatistiksel test, IBM SPSS 22,0 (Statistical Package fort he Social Sciences) programı ile kıyaslandı. Anlamlıık seviyesi $\mathrm{a}=0.05$ olarak alındı.

\section{BULGULAR}

Gluma Desensitizer uygulanan örnekler, Teethmate Desensitizer uygulanan örnekler ile istatiksel olarak karşılaştırıldığında dentin tabakasındaki adeziv siman bağlantısı daha yüksek bulundu (sırasıyla 11,84 \pm 1,39 MPa, 2,46 — 1,91 MPa) (Tablo 2,3). Oklüzal yüzeyde adeziv bağlantı analiz değerleri arasındaki fark istatistiksel olarak anlamlıdır $(\mathrm{p}<0.05)$

(Tablo 4)

\begin{tabular}{|l|l|l|}
\hline & Gluma Desensitizer & Teethmate Desensitizer \\
\hline 1.örnek & $12,75 \mathrm{MPa}$ & $4,32 \mathrm{MPa}$ \\
\hline 2.örnek & $13,92 \mathrm{MPa}$ & $4,57 \mathrm{MPa}$ \\
\hline 3.örnek & $10,42 \mathrm{MPa}$ & $3,17 \mathrm{MPa}$ \\
\hline 4.örnek & $10,37 \mathrm{MPa}$ & $1,20 \mathrm{MPa}$ \\
\hline 5.örnek & $12,21 \mathrm{MPa}$ & $2,10 \mathrm{MPa}$ \\
\hline 6.örnek & $11,43 \mathrm{MPa}$ & $4,32 \mathrm{MPa}$ \\
\hline 7.örnek & $10,42 \mathrm{MPa}$ & 0 \\
\hline 8.örnek & $13,22 \mathrm{MPa}$ & 0 \\
\hline
\end{tabular}

Tablo 2: Makaslama Testinin sonuçları

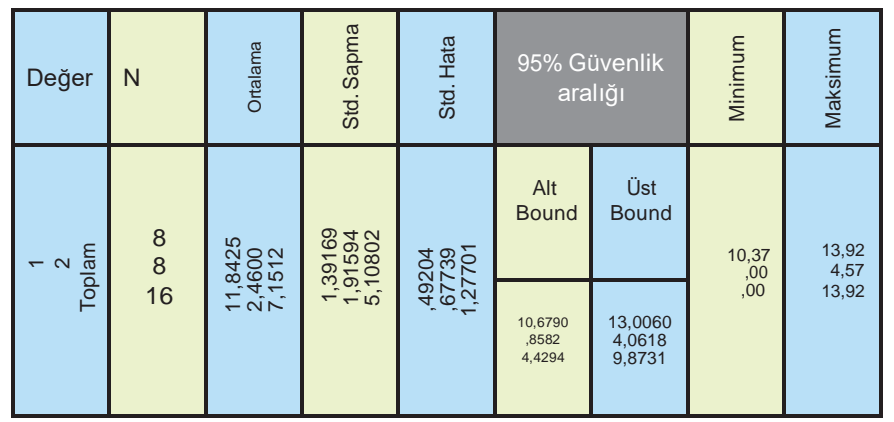

Tablo 3: Makaslama kuvvetleri değerlerinin tanımlayıcı istatistikleri

\begin{tabular}{|c|c|c|c|c|c|}
\hline Değer & $\begin{array}{c}\text { Kareler } \\
\text { toplamı }\end{array}$ & df & Kare Ortalaması & F & Sig \\
\hline $\begin{array}{c}\text { Gruplar- } \\
\text { arası } \\
\text { Grup içi } \\
\text { Toplam }\end{array}$ & $\begin{array}{c}352,125 \\
39,253 \\
391,379\end{array}$ & $\begin{array}{c}1 \\
15\end{array}$ & $\begin{array}{c}352,125 \\
2,804\end{array}$ & 125,588 &, 000 \\
\hline
\end{tabular}

Tablo 4: Gruplar arası One way Anova istatistiksel değerlendirilmesi

Her iki grup için hazırlanan deney örnekleri, SEM'de farklı büyütmelerde incelendi. İncelenen örnek yüzeylerinde adeziv ayrılma görülmedi, koheziv ayrılma görüldü

(Resim 6,7,8,9).

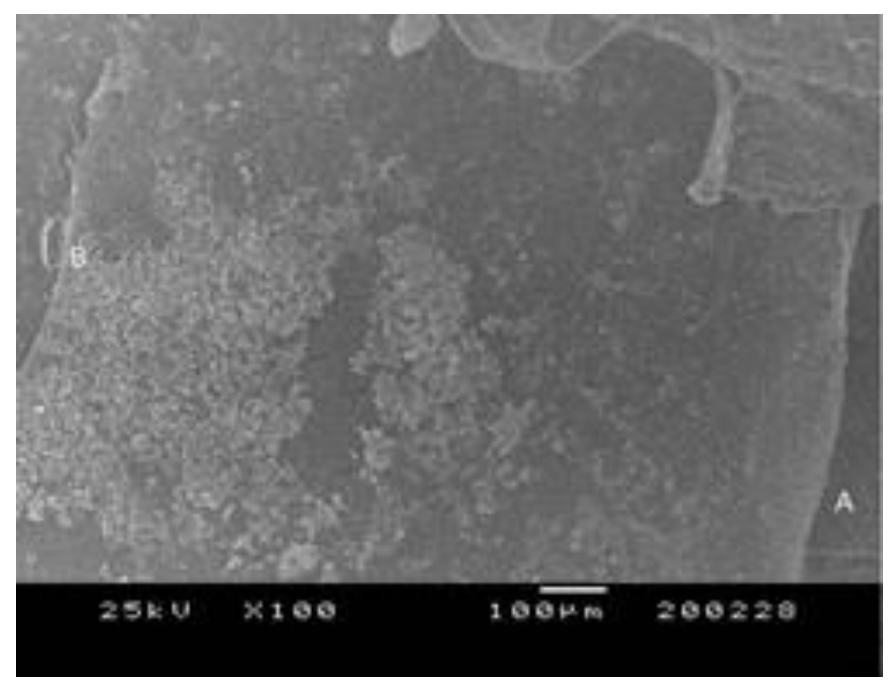

Resim 6: Deney örneğinin SEM görüntüsü

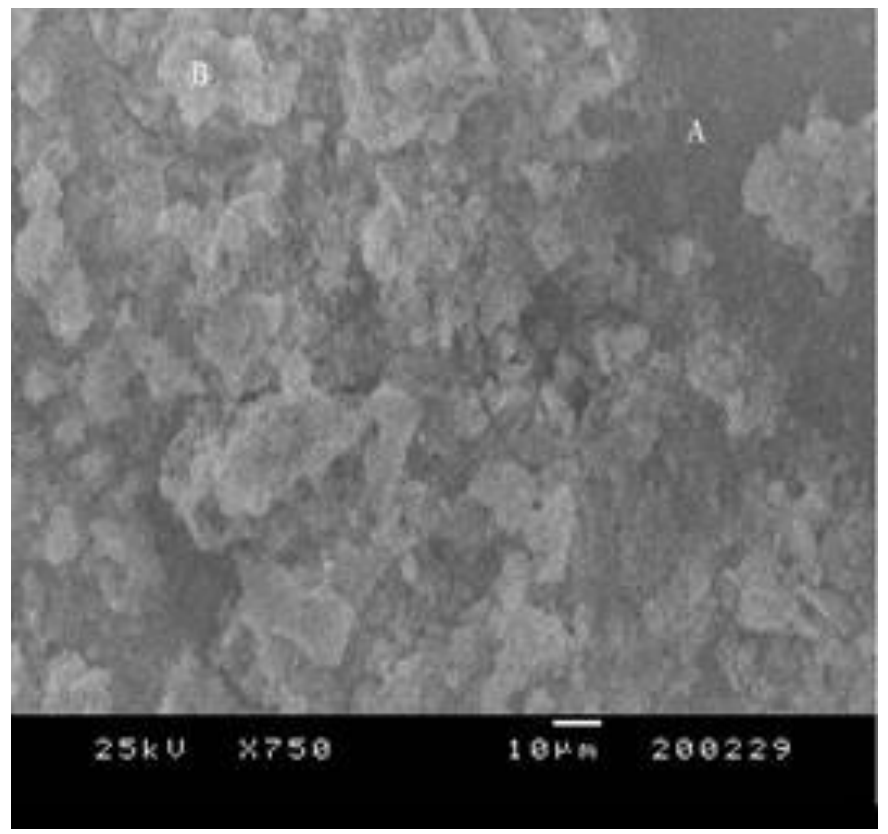

Resim 7: Deney örneğinin SEM görüntüsü 


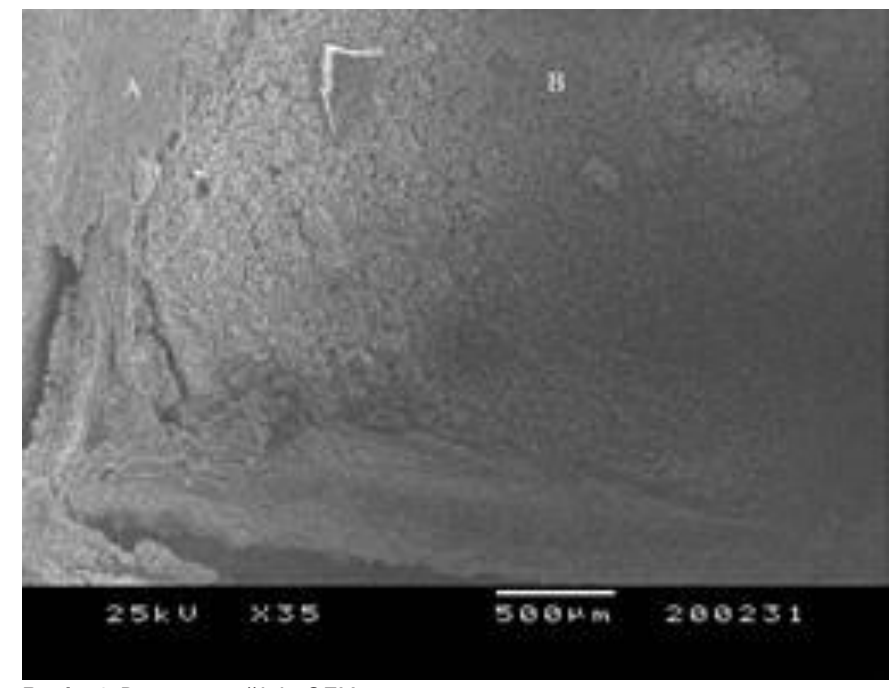

Resim 8:Deney örneğinin SEM görüntüsü

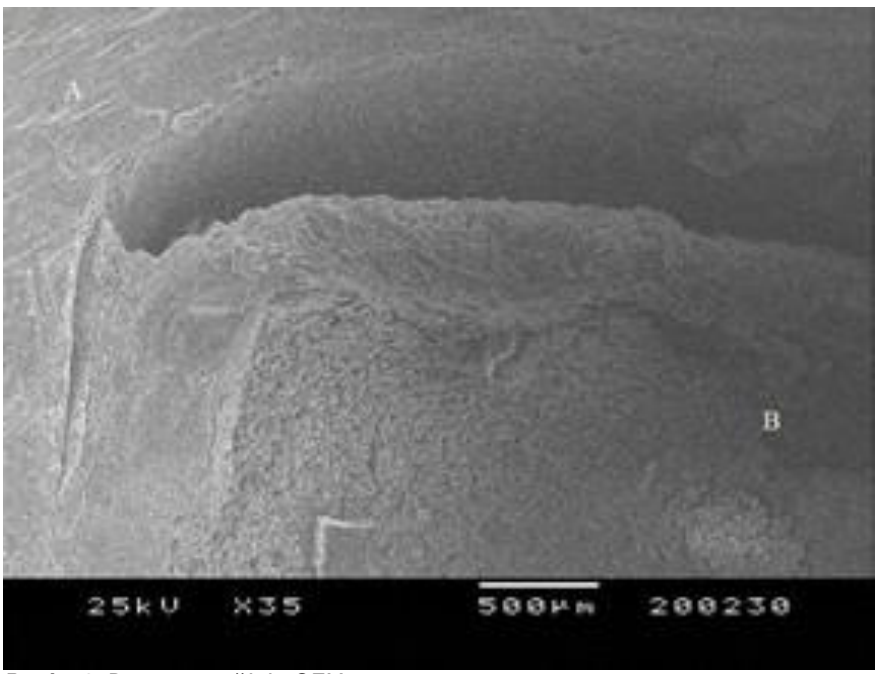

Resim 9:Deney örneğinin SEM görüntüsü

\section{TARTIŞMA}

Sabit protetik restorasyonların retansiyonu, prepare dişin yüksekliği, açıSı, simantasyonda kullanılan simanın restorasyon ve destek diş yüzeyleri arasında oluşan bağlantı gibi birçok faktörden etkilenmektedir. ${ }^{10}$ Kron ve kavite preparasyonlarından sonra sıklıkla karşılaşılan dentin hassasiyetinin tedavisinde kullanılan ajanların, simanların ve dentin bağlayıcı sistemlerin bağlanma dayanımlarını etkilediği bildirilmiştir. ${ }^{11,12,13,14,15}$ Yapılan çalışmalarda, hassasiyet giderici ajanların, adeziv sistemlerde prepare diş yüzeyinde dentin ile yaptıkları bağlantıda önemli bir rol oynayan dentin geçirgenliğini \%60-80 oranında azalttığı gözlenmiştir. ${ }^{16}$ Ayrıca bu ajanların içeriğindeki bazı maddeler dentinin organik yapısı ile kimyasal etkileşim sonucunda simanın örtücü ve bağlayıcı özelliklerini de etkilemektedir. ${ }^{12}$ İki farkı hassasiyet giderici ajanın, adeziv simantasyondaki bağlantıya etkisi- nin incelendiği çalışmamızda, hassasiyet giderici ajanların adeziv simantasyondaki bağlantıya etkili olduğu bulundu $(p<0.05)$. \%5'lik gluteraldehit ve \%36'lık HEMA içeren ajan uygulanan gruptaki bağlantı kuvvetinin, kalsiyum fosfat içeren ajan uygulanan gruptaki bağlantı kuvvetine göre daha fazla olduğu görüldü.

Hassasiyet giderici ajanların dentin geçirgenliği üzerine etkisinin incelendiği bir çalışmada ${ }^{17}$ karşılaştırılan ajanlar, tübüllerin üzerini kaplayanlar, protein ve kristal çöktürenler şeklinde sınıflandırılmış ve tübül içine kristal çöktüren ajanların dentin geçirgenliğini diğerlerine oranla daha fazla düşürdüğü bulunmuştur. Aşırı dentin duyarılıığının tedavisinde sıklıkla kullanılan florid içeren ajanlar, dentin tübülleri içerisine çözünmeyen sodyum ve kalsiyum florid kristalleri çökmesini sağlayarak etki ederken, ${ }^{12,18,19}$ rezin içeren ajanlar ise rezin tag şekillenmesi ve ince bir tabaka polimerize olmuş rezin yüzeyi oluşturup dentin tübüllerini kaplayarak duyarlılık giderici etkinin uzun ömürlü olmasını sağlarlar. ${ }^{20}$

Soeno ve ark.12'nın yaptıkları bir çalışmada, 3 farkı hassasiyet giderici ajanın 2 farklı adeziv rezin simanın makaslama bağlantı dayanımı üzerine etkileri değerlendirilmiş ve en düşük bağlanma dayanımının her iki adeziv simanda da florid içerikli ajan (Saforide), en yüksek bağlanma dayanımının ise HEMA ve gluteraldehit içerikli ajan (Gluma CPS) ile elde edildiği bildirilmiştir. Yapılan başka bir çalışmada, ${ }^{21}$ bir polimerize edilen (All-Bond 2) ve bir polimerize edilmeyen gluteraldehit içeren (Gluma Desensitizer) iki farklı hassasiyet giderici ajan uygulamasının dört farklı simanın kron retansiyonuna etkisi incelenmiş ve polimerize edilebilir hassasiyet giderici ajan ile hem ışıkla hem de kimyasal olarak polimerize olan rezin simanın birlikte kullanılması ile en yüksek bağlanma dayanımı elde edildiği bildirilmiştir. Polimerize edilmeyen gluteraldehit içeren hassasiyet giderici ajanın çinko fosfat ve geleneksel cam iyonomer simanın bağlanma dayanımlarını düşürdüğü belirtilmiştir. Mausner ve ark. ${ }^{21}$ bir rezin esaslı hassasiyet giderici ajanın ve bir geleneksel bonding ajanın, simanların dentine bağlanma dayanımları üzerine etkilerini inceledikleri çalışmalarında, hassasiyet giderici ajan uygulamasından sonra cam iyonomer siman ile bağlantı 
dayanımı değerlerinin kontrol grubuna oranla düştüğünü ve rezin siman ile daha yüksek bağlantı değerleri elde edildiğini bildirmiştir.

Hassasiyet giderici ajanların restorasyonun dentine bağlanma gücüne etkisini incelemek için, 40 hayvan dişi kullanılan bir çalışmada, ${ }^{22}$ dişler 4 gruba ayrılmıştır. 1. grup kontrol grubu olarak ayrılırken, 2. grupta Gluma Desensitizer, 3. g rupta Oxa-Gel, 4. grupta düşük frekansta lazer (MMOptics) kullanılmıştır. Bukkal yüzeylerinde silikon karbid abraziv kağıtlarla midkoronal dentin açığa çıkartıldıktan sonra, hassasiyet giderici uygulanmıştır. Sonrasında asitlenerek yıkanmış ve adeziv uygulanarak ışınlanmıştır. Kompozit re- zin ile üst kısmı tamamlanıp mikroçekme testi uygulanmıştır. Dentin hassasiyet giderici ajanlarla tedavi edilen örnekler (Gluma hariç), tedavi edilmeyen örneklere göre belirgin şekilde düşük ortalamalarda bağlanma kuvveti göstermiş- lerdir. Sadece Gluma Desensitizer bağlanma gücü değerine olumsuz bir etki yapmamıştır. ${ }^{22}$

Bir başka çalışmada ${ }^{21}$ kron preparasyon yüzeyi kontrol edilmiş ve döküm kron restorasyonlarda dentin hassasiyet gidericiler ile konvansiyonel simantasyon ajanlarının bağlanma güçleri incelenmiştir. Tüm kombinasyonlarda, sadece Gluma Desensitizer hariç, kron retansiyonu belirgin olarak azalmıştır. Rezin siman ve rezin modifiye siman, AllBond 2 dentin hassasiyet gidericilerle kullanıldığında kron retansiyon değerinde belirgin artış olduğu gösterilmiştir. ${ }^{21}$

$\mathrm{Bu}$ çalışmalarla benzer sonuçlar elde edilen çalışmamızda Gluma Desensitizer (\%5'lik gluteraldehit ve \%36'lık HEMA içerikli) hassasiyet giderici ajanın, Teethmate Desensitizer (kalsiyum fosfat içerikli) hassasiyet giderici ajana göre adeziv simantasyondaki bağlanma dayanımını artırdığı görülmüştür.

\section{SONUÇ}

Yapmış olduğumuz in vitro çalışmanın sınırları içerisinde aşağıdaki sonuçlara ulaşıldı:

1. Dentin hassasiyet giderici 2 farklı içerikteki ajanın, rezin bazlı adeziv simanla dentine bağlanma kuvvetleri arasındaki fark istatiksel olarak anlamlıdır $(p<0.05)$.

2. Gluteraldehit ve HEMA (hidroksil metil metakrilat) içerikli dentin hassasiyet giderici ajanın adeziv simantasyondaki bağlantı kuvveti, Kalsiyum Fosfat içerikli dentin hassasiyet giderici ajanın adeziv simantasyondaki bağlantı kuvvetinden daha fazladır.

\section{KAYNAKLAR}

7tepeklinik
1. Holland GR, Narhi MN, Addy M, Gangarosa L, Orchardson R. Guidelines for the design and conduct of clinical trials on dentine hypersensitivity. J Clin Periodontol 1997; 24: 8-13.

2. Rees JS. The prevalence of dentine hypersensitivity in general dental practice in the UK. J Clin Periodontol 2000;

27: $860-865$

3. Brannstrom M. Etiology of dentin hypersensitivity. Proc Finn Dent Soc 1992; 88: 7-13.

4. Christensen GJ. Preventing postoperative tooth sensitivity in class I, II and V restorations. J Am Dent Assoc 2002; 133: $229-331$

5. Perdigao J. Dentin bonding-variables related to the clinical situation and the substrate treatment. Dent Mater 2010; 26: 24-37.

6. Eyüpoğlu GB, Yeşilyurt C. Dentin hassasiyet giderici ajanların tek aşamalı bir self-etch adezivin makaslama bağlanma dayanımına etkisi. Cumhuriyet Dental Journal 2014; 17334 349.

7. Akça T, Yazıcı AR, Çelik C, Özgunaltay G, Dayangaç B. The effect of desensitizing treatments on the bond strength of resin composite to dentin mediated by a self-etching primer Oper Dent 2007; 32: 451-456.

8. Arısu HD, Dalkılıç E, Uçtaşı MB. Effect of desensitizing agents on the microtensile bond strength of a twostep selfetch adhesive to dentin. Oper Dent 2011; 36: 153-161.

9. Al Qahtani MQ, Platt JA, Moore BK, Cochran MA. The effect on shear bond strength of rewetting dry dentin with two desensitizers. Oper Dent 2003; 28: 287-296.

10. Wolfart S, Linnemann J, Kern M. Crown retantion with use of different sealing systems on prepared dentine. J Oral Rehabil 2003; 30: 1053-1061.

11. Jain P, Vargas MA, Denehy GE, Boyer DB. Dentin desensitizing agents: SEM and X-ray microanalysis assessment. Am J Dent 1997; 10: 21-26.

12. Soeno K, Taira Y, Matsumura H, Atsuta M. Effect of desensitizers on bond strength of adhesive luting agents to dentin. J Oral Rehabil 2001; 28: 1122-1128.

13. Al Qahtani MQ, Platt JA, Moore BK, Cochran MA. The 
effect on shear bond strength of rewetting dry dentin with two desensitizers. Oper Dent 2003; 28: 287-296.

14. Mausner IK, Goldstein GR, Georgescu M. Effect of two dentinal desensitizing agents on retention of complete cast coping using four cements. J Prosthet Dent 1996; 75: 129 134.

15. Pashley DH, Carvalho RM, Pereira JC, Villanueva R, Tay $F R$. The use of oxalate to reduce dentin permeability under adhesive restorations. Am J Dent 2001; 14: 89-94.

16. Seara SF, Erthal BS, Ribeiro M, Kroll L, Pereira GD. The influence of a dentin desensitizer on the microtensile bond strength of two bonding systems. Oper Dent 2002; 27: 154160.

17. Kolker JL, Vargas MA, Armstrong SR, Dawson DV. Effect of desensitizing agents on dentin permeability and dentin tubule occlusion. J Adhes Dent 2002; 4: 211-221.

18. Jacobsen PL, Bruce G. Clinical Dentin Hypersensitivity: Understanding the Causes and Prescribing a Treatment. J Contemp Dent Pract 2001; 2: 1-12.

19. Kanapka JA. Current treatment of Dentinal hypersensitivity. A new agent. Compend Contin Educ Dent 1982; 3: $118-120$

20. Pereira JC, Martineli AC, Tung MS. Replica of human dentin treated with different desensitizing agents: a methodological SEM study in vitro. Braz Dent J 2002; 13: 75-85.

21. Yim NH, Rueggeberg FA, Caughman WF, Gardner FM, Pashley DH. Effect of dentin desensitizers and cementing agents on retention of full crowns using standardized crown preparations. J Prosthet Dent 2000; 83: 459-465.

22. Aranha AC, Siqueina Junior Ade S, Cavalcante LM, Pimenta LA, Marchi GM. Microtensile bond strengths of composite to dentin treated with desensitizer products. J Adhes Dent 2006; 8: 85-90. 
7tepeklinik 